\title{
Linkage of Fusidic Acid Resistance to the Penicillinase Plasmid in Staphylococcus aureus
}

\author{
By R. W. LACEY AND J. GRINSTED \\ Department of Bacteriology, University of Bristol, The Medical School, \\ University Walk, BS8 ITD \\ (Received I7 May 1972)
}

\begin{abstract}
SUMMAR Y
In four out of five strains of Staphylococcus aureus examined, genes determining fusidic acid resistance were associated with a penicillinase plasmid. In one strain (FAR 5), although the linkage was unstable, resistance to fusidic acid was co-transduced with resistance to cadmium ions and penicillinase production. Further evidence for a single plasmid in this strain was obtained by studying the physical nature of the plasmid DNA. The molecular weight of the entire linkage group was about I 6 million daltons; the molecular weight of the residual plasmid after loss of fusidic acid resistance was about I 5 million.
\end{abstract}

\section{INTRODUCTION}

In Staphylococcus aureus, two or more genes determining resistance to antibiotics are rarely linked; Dyke, Parker \& Richmond (I970) found that in about 100 strains there was no linkage of other antibiotic resistances to penicillinase. However, Mitsuhashi, Hashimoto, Kono \& Morimura (1965) found an association of erythromycin resistance with penicillinase. Evans \& Waterworth (1966) showed that among Io strains resistant to fusidic acid, this resistance was linked to penicillinase production in one, and probably to both tetracycline and neomycin resistance in another. Annear \& Grubb (1972) provide evidence for linkage of kanamycin resistance to penicillinase production in one strain.

We have found that in four out of five clinical strains of Staphylococcus aureus examined, fusidic acid resistance is linked to the penicillinase plasmid. In contrast, genes determining resistance to fusidic acid in mutants selected in vitro are probably chromosomally located. Evidence for this linkage in clinical strains has been obtained from (i) co-segregation and cotransduction findings, and (ii) isolation and characterization of the plasmid DNA from one strain.

\section{METHODS}

Strains. Strains FAR I, FAR 2 and FAR 3 were recently isolated from patients in Birmingham and kindly supplied by Dr G. A. J. Ayliffe. Strains FAR 4 and FAR 5 were recently isolated from patients in Bristol. Thrice-plated colonies from each strain were stored on nutrient agar slopes at room temperature for up to 6 months without subculture.

Special materials. Lysostaphin was obtained from Schwarz/Mann Biochemicals, Orangburg, New York, U.S.A.; other materials have been described by Grinsted et al. (1972). Fusidic acid was obtained from Leo Laboratories, Hayes, Middlesex, as the commercially available sodium salt, and stored as a $2.5 \mathrm{mg} / \mathrm{ml}$ soln. at $4{ }^{\circ} \mathrm{C}$.

Media, bacteriophage typing, antiobiotic sensitivity, mitomycin $C$ induction and transduction 
were as previously described (Lacey, I97I). Resistance to mercury, arsenate and cadmium ions was determined by the disc method of Dyke et al. (1970). In addition, the minimum inhibitory concentrations (MICs) of antibiotics and metal ions were determined for a proportion of the isolates by a plate incorporation method. Penicillinase production was detected by the starch-iodine method of Dyke, Jevons \& Parker (I966).

Loss of antibiotic resistance was determined by inoculating about $10^{4}$ organisms from overnight broth cultures at $37^{\circ} \mathrm{C}$ into warmed nutrient broth and incubation continued for I $8 \mathrm{~h}$ at $43^{\circ} \mathrm{C}$. Dilutions were plated on nutrient agar to give about 200 colonies/plate. Loss of resistance was detected by replication to media containing sodium fusidate $(2 \mu \mathrm{g} / \mathrm{ml})$ or cadmium acetate $\left(10^{-4} \mathrm{M}\right)$.

Isolation and analysis of plasmid DNA. Cultures, grown overnight in nutrient broth at $37^{\circ} \mathrm{C}$ in an orbital shaker, were diluted I : I00 or I : 200 with fresh warmed broth; $\left[\mathrm{Me}^{-3} \mathrm{H}\right]-$ thymidine (10 $\mu \mathrm{Ci} / \mathrm{ml}, 5 \mathrm{Ci} / \mathrm{mmol}$ ) was added and incubation continued at $37^{\circ} \mathrm{C}$. After growth for 3 to 4 doubling times, the cultures were harvested at $4{ }^{\circ} \mathrm{C}$ the bacteria washed with SET buffer (0.05 M-tris (hydroxymethyl)aminomethane, $0 . \mathrm{I}_{5} \mathrm{M}-\mathrm{NaCl}$, O. I M-disodium ethylenediaminetetraacetate, $\mathrm{pH} 8 \cdot 0$ ), resuspended in SET buffer containing ribonuclease $\mathrm{A}$ $(500 \mu \mathrm{g} / \mathrm{ml})$ and lysostaphin $(50 \mu \mathrm{g} / \mathrm{ml})$ and incubated at $37^{\circ} \mathrm{C}$ for $3 \mathrm{~min}$, after which sodium dodecyl sarcosinate was added to $0.8 \%(\mathrm{w} / \mathrm{v})$. This treatment resulted in essentially complete lysis. Radioactive plasmid DNA was prepared from these lysates by ethidium bromide $/ \mathrm{CsCl}$-gradient centrifugation, and analysed on 5 to $20 \%$ sucrose gradients at $20{ }^{\circ} \mathrm{C}$, as described by Grinsted et al. (1972).

\section{RESULTS}

Properties of strains. On account of antibiotic sensitivity and phage-typing pattern the strains were distinct (Tables I, 3). Four of the strains were resistant to cadmium but sensitive to mercury and arsenate ions - a pattern not previously described in clinical strains of staphylococci, resistance to cadmium having been always linked with resistance to arsenate ions (Richmond, 1969; Dyke et al. 1970).

Loss of fusidic acid and cadmium ion resistance after growth at $43{ }^{\circ} \mathrm{C}$. Loss of resistance to fusidic acid was always associated with loss of resistance to cadmium ions and penicillinase production in strains FAR I and FAR 4 after growth at $43{ }^{\circ} \mathrm{C}$ (Table 2). Six colonies of the sensitive segregants from strain FAR I and FAR 4 (denoted $\mathrm{fus}^{-}, \mathrm{cad}^{-}$, pen ${ }^{-}$) were tested for sensitivity to other antibiotics and metal ions and phage-typed. All resembled the corresponding wild strains in these properties, except FAR I $\mathrm{fus}^{-}, \mathrm{cad}^{-}, \mathrm{pen}^{-}$colonies which showed a widening of phage-typing pattern (Table 3).

Resistance to fusidic acid was stable in strain FAR 3, but loss of cadmium ion resistance was linked to loss of penicillinase production and resistance to mercury and arsenate ions. There was therefore no evidence for linkage of fusidic acid resistance with the penicillinase plasmid in this strain.

In strains FAR 2 and FAR 5, loss of resistance to fusidic acid was often, but not always, associated with loss of resistance to cadmium ions and penicillinase production. The latter two characters were always linked. Forty-two of 12400 colonies of strain FAR 2 had lost resistance to fusidic acid, together with resistance to cadmium ions and penicillinase production; I5 colonies had lost fusidic acid resistance only. No colonies were detected that were sensitive to cadmium ions and resistant to fusidic acid. The findings for strain FAR 5 were similar (Table 2). Six colonies of each type of segregant from strains FAR 2 and FAR 5 were phage-typed. The loss of fusidic acid resistance only was not associated with any alteration 
Table I. Antibiotic and metal ion sensitivity of five fusidic acid-resistant strains of Staphylococcus aureus

\begin{tabular}{|c|c|c|c|c|c|c|c|c|c|c|}
\hline \multirow[b]{2}{*}{ Strain no. } & \multicolumn{9}{|c|}{ Resistance to* } & \multirow{2}{*}{$\begin{array}{c}\text { MIC } \dagger \\
\text { of } \\
\text { sodium } \\
\text { fusidate } \\
(\mu \mathrm{g} / \mathrm{ml})\end{array}$} \\
\hline & $\mathbf{P}$ & $\mathrm{S}$ & $T$ & $\mathrm{E}$ & $\mathrm{N}$ & $\mathbf{M}$ & $\mathrm{Hg}$ & As & $\mathrm{Cd}$ & \\
\hline FAR I & + & $r$ & $\mathrm{r}$ & $r$ & $r$ & $\mathbf{r}$ & s & $\mathrm{s}$ & $\mathrm{r}$ & 16 \\
\hline FAR 2 & + & $r$ & $r$ & $r$ & s & $\mathbf{r}$ & s & s & $\mathrm{r}$ & I 6 \\
\hline FAR 3 & + & $\mathrm{s}$ & s & s & $\mathrm{s}$ & s & $\mathrm{r}$ & $\mathrm{r}$ & $\mathrm{r}$ & 16 \\
\hline FAR 4 & + & $r$ & s & $r$ & $\mathrm{r}$ & s & s & $\mathrm{s}$ & $\mathrm{r}$ & 16 \\
\hline FAR 5 & + & s & s & $s$ & s & s & $\mathrm{s}$ & $\mathrm{s}$ & $r$ & 16 \\
\hline
\end{tabular}

* Penicillinase producer (P); Resistance to streptomycin (S), tetracycline (T), erythromycin (E), neomycin, $(\mathrm{N})$, methicillin (M), mercury ions ( $\mathrm{Hg}$ ), arsenate ions (As), cadmium ions (Cd).

$\dagger$ MIC for control sensitive straphylococci is about $0.1 \mu \mathrm{g} / \mathrm{ml}$.

$r=$ resistant; $s=$ sensitive.

Table 2. Segregation of fus , $^{-} \mathrm{dd}^{-}$and pen $^{-}$colonies from five fusidic acid-resistant strains after growth at $43{ }^{\circ} \mathrm{C}$

$\begin{array}{rcccc}\text { Strain } & \begin{array}{c}\text { No. of colonies } \\ \text { examined }\end{array} & \begin{array}{c}\text { No. of fus } \\ \mathrm{cad}^{+}, \mathrm{pen}^{+}\end{array} & \begin{array}{c}\text { No. of fus } \\ \mathrm{cad}^{-}, \mathrm{pen}^{-}\end{array} & \begin{array}{c}\text { No. of fus } \\ \mathrm{cad}^{-}, \mathrm{pen}^{-}\end{array} \\ \text {FAR I } & 8370 & 0 & 0 & 3 \mathrm{I} \\ \text { FAR 2 } & 12400 & 15 & 0 & 42 \\ \text { FAR 3 } & 4200 & 0 & 65 & 0 \\ \text { FAR 4 } & 8510 & 0 & 0 & 29 \\ \text { FAR 5 } & 8300 & \text { I2 } & 0 & 27\end{array}$

Table 3. Comparison of phage-typing pattern of wild strains and fus ${ }^{-}$, pen $^{-}$, cad $^{-}$segregants

\begin{tabular}{|c|c|c|c|c|}
\hline $\begin{array}{l}\text { Wild } \\
\text { strain }\end{array}$ & $\begin{array}{l}\text { Phage-typing } \\
\text { pattern }\end{array}$ & $\begin{array}{l}\text { Sensitive } \\
\text { segregant }\end{array}$ & $\begin{array}{l}\text { No. of } \\
\text { segregants } \\
\text { phage } \\
\text { typed }\end{array}$ & $\begin{array}{c}\text { Phage-typing } \\
\text { pattern of } \\
\text { segregant (R.T.D.)* }\end{array}$ \\
\hline FAR I & $77 / 83 \mathrm{~A} / 84$ & fus ${ }^{-}, \mathrm{cad}^{-}, \mathrm{pen}^{-}$ & 6 & $29 / 79 / 77 / 83 \mathrm{~A} / 84 / 88$ \\
\hline \multirow[t]{2}{*}{ FAR 2} & $\begin{array}{l}42 \mathrm{E} / 47 / 54 / 77 / 83 \mathrm{~A} / \\
84 / 85\end{array}$ & fus cad $^{+}$, pen $^{+}$ & 10 & $\begin{array}{l}42 \mathrm{E} / 47 / 54 / 77 / 83 \mathrm{~A} / \\
84 / 85\end{array}$ \\
\hline & & fus $s^{-}, \mathrm{cad}^{-}, \mathrm{pen}^{-}$ & IO & $\begin{array}{c}29 / 79 / 42 \mathrm{E} / 47 / 54 / 77 / \\
83 \mathrm{~A} / 84 / 85 / 88\end{array}$ \\
\hline FAR 3 & $77 / 83 \mathrm{~A} / 85 / 8 \mathrm{I}$ & cad $^{-}$, pen $^{-}$ & 6 & $77 / 83 \mathrm{~A} / 85 / 8 \mathrm{I}$ \\
\hline FAR 4 & $3 \mathrm{~A}$ & fus $^{-}, \mathrm{cad}^{-}, \mathrm{pen}^{-}$ & 6 & $3 \mathrm{~A}$ \\
\hline \multirow[t]{2}{*}{ FAR 5} & $79 / 47 / 53 / 54 / 84 / 85$ & $\mathrm{fus}^{-}, \mathrm{cad}^{+}, \mathrm{pen}^{+}$ & 10 & $79 / 47 / 53 / 54 / 84 / 85$ \\
\hline & & fits $^{--}, \mathrm{cad}^{-}, \mathrm{pen}^{-}$ & 10 & $79 / 47 / 53 / 54 / 84 / 85$ \\
\hline
\end{tabular}

in typing pattern; but the loss of genes determining resistance to cadmium ions and production of penicillinase increased the phage susceptibility of strain FAR 2 (Table 3). The widening of typing pattern was not due to the loss of an entire prophage in either strain FAR I or FAR 2 since mitomycin C-induced lysates from the wild strains did not form plaques on the corresponding $\mathrm{fus}^{-}, \mathrm{cad}^{-}$, pen-, derivatives.

Cultures that had lost fusidic acid resistance only (FAR $2 \mathrm{fuS}^{-}, \mathrm{cad}^{+}, \mathrm{pen}^{+}$and FAR $5 \mathrm{fuS}^{-}$, $\mathrm{cad}^{+}, \mathrm{pen}^{+}$) were investigated for loss of cadmium ion resistance after growth at $43{ }^{\circ} \mathrm{C}$. In each culture about $0 . \mathrm{I} \%$ of cocci after $\mathrm{I} 8 \mathrm{~h}$ had lost resistance to cadmium ions together with penicillinase production. These derivatives from FAR 2 showed the widening in phage- 
Table 4. Co-transduction of resistance to fusidic acid and penicillinase production from a lysate of strain FAR 5 to recipient FAR 5 fus $^{-}$, cad-, pen- selecting for cadmium resistance

No. of transductants $/ \mathrm{ml}$ lysate of donor resistant to

$\begin{array}{cccc}\text { u.v. exposure } & \begin{array}{c}\text { Cadmium } \\ \text { ions }\end{array} & \begin{array}{c}\text { Fusidic } \\ \text { acid }\end{array} & \begin{array}{c}\text { Penicillin } \\ \text { (penicillinase) }\end{array} \\ 0 & 624 & 616 & 624 \\ 15 \mathrm{~S} & 306 & 295 & 305 \\ 30 \mathrm{~s} & 142 & 136 & 142 \\ 1 \mathrm{~min} & \mathrm{II} & \mathrm{I} 5 & \mathrm{I} 14 \\ 2 \mathrm{~min} & \mathrm{I} 8 & 16 & \mathrm{I} 8 \\ 5 \mathrm{~min} & 2 & 2 & 2\end{array}$

typing pattern similar to those in which the three resistance genes had apparently been lost simultaneously. Thus, in strain FAR 2 there is little doubt that genes determining phage susceptibility are harboured by the 'penicillinase' plasmid. In strain FAR I genes determining both resistance to fusidic acid and phage-typing pattern are borne by this plasmid.

The relationship of the genes determining resistance to fusidic acid to the 'penicillinase' plasmid in strains FAR 2 and FAR 5 is uncertain; the former is frequently, but not always, lost in association with the 'penicillinase' plasmid. There are two possibilities: (i) there is a single linkage group in the cell that harbours genes for resistance to fusidic acid and cadmium ions and penicillinase production. This is unstable, sometimes the part determining resistance to fusidic acid becoming detached and lost; (ii) alternatively two sets of genes are located on different plasmids which may be lost independently, but some factor tends to favour their simultaneous loss.

Transduction of fusidic acid resistance from strain FAR 5. Mitomycin C-induced lysates of strain FAR 5 were exposed to u.v. light for various intervals and added to the recipient (FAR $5 \mathrm{fus}^{-}, \mathrm{cad}^{-}, \mathrm{pen}^{-}$). Transductants were selected on media containing cadmium acetate $\left(\mathrm{IO}^{-4} \mathrm{M}\right)$. (Selection with sodium fusidate is unsatisfactory because sensitive staphylococci exhibit a high incidence of mutants resistant to this substance.) Resultant colonies were examined for resistance to fusidic acid and penicillinase production. Co-transduction of resistance to fusidic acid and cadmium ions, and penicillinase production usually occurred. A typical result is shown in Table 4. The effect of u.v. light on the transduction frequency was typical of a plasmid gene (Arber, 1960). It therefore seems likely that in strain FAR 5 the genes determining all three resistances are located on a single extrachromosomal linkage group.

Resistance to fusidic acid in vitro. A possible explanation for the linkage of resistance to fusidic acid to the 'penicillinase' plasmid in clinical strains is that mutation to fusidic acid resistance occurred at a locus on this plasmid under natural conditions. Attempts to repeat this in vitro have failed. Overnight broth cultures of strain 2273 and 8325 (524), which harbour, respectively, an uncharacterized plasmid and an $\alpha$ plasmid (Richmond, 1967), were plated on nutrient agar containing fusidic acid $(2 \mu \mathrm{g} / \mathrm{ml})$ and incubated for $40 \mathrm{~h}$ at $37^{\circ} \mathrm{C}$. Mutation to fusidic acid resistance occurred at a frequency of about $5 \times 10^{-8}$ in each strain. A similar frequency was obtained when strains 2273 and 8325 that had lost their penicillinase plasmids were plated. Thirty fusidic acid-resistant colonies were picked from each strain harbouring the penicillinase plasmid. Each colony was inoculated into broth and incubated overnight. The broths for each strain were combined and induced with mitomycin $\mathrm{C}$. The lysates were added to recipient 8325 and transductants selected with cadmium acetate $\left(\mathrm{IO}^{-4} \mathrm{M}\right)$. The resulting colonies were examined for fusidic acid resistance. From about $\mathrm{IO}^{3}$ 


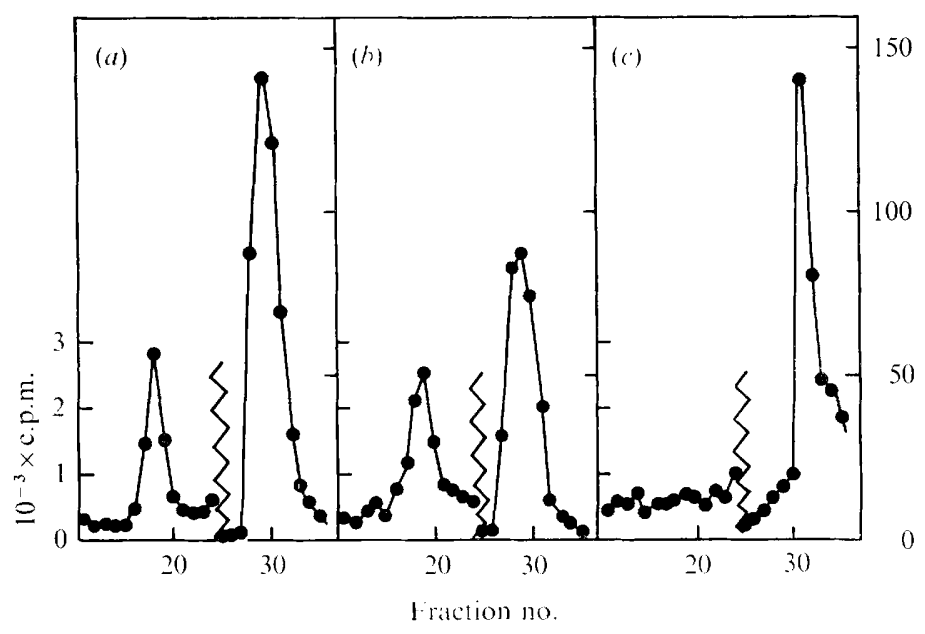

Fig. I. Ethidium bromide/CsCl-gradient analysis of strain FAR 5 and its derivatives. Radioactive lysates of strains FAR $5(a)$, FAR $5 \mathrm{fus}^{-}, \mathrm{cad}^{\prime}, \mathrm{pen}^{+}(\mathrm{b})$, and FAR $5 \mathrm{fus}^{-}, \mathrm{cad}^{-}$, pen- $(c)$ were analysed on ethidium bromide/CsCl-gradients. Note the changes of scale between fractions 24 and 25 .

transductants, from each lysate, none was fusidic acid-resistant. Since strain 8325 wild does not harbour plasmid genes (Novick \& Bouanchaud, 197I), the locus of fusidic acid resistance in mutants of this strain must be chromosomal. The presence of the penicillinase plasmid in this strain and 2273 did not affect the mutation rate or locus to fusidic acid resistance.

Plasmid DNA in strain FAR 5 and its derivatives. Strain FAR 5 and its derivatives FAR 5 fus ${ }^{-}$, $\mathrm{cad}^{+}$, pen ${ }^{+}$and FAR $5 \mathrm{fus}^{-}, \mathrm{cad}^{-}$, pen ${ }^{-}$were analysed by ethidium bromide/CsCl-gradient centrifugation (Fig. I). Lysates of strain FAR 5 (Fig. I $a$ ) and FAR $5 \mathrm{fus}^{-}, \mathrm{cad}^{+}, \mathrm{pen}^{+}$(Fig. I $b$ ) contained a satellite band of DNA on the dense side of the main chromosomal band. Such a satellite in ethidium bromide/CsCl-gradients represents covalently closed circular DNA (CCC-DNA). Lysates of strain FAR $5 \mathrm{fus}^{-}, \mathrm{cad}^{-}$, pen ${ }^{-}$did not contain such a satellite (Fig. I c). It is inferred therefore that the CCC-DNA in strains FAR 5 and FAR $5 \mathrm{fus}^{-}, \mathrm{cad}^{+}, \mathrm{pen}^{+}$ is the plasmid(s) which carries the genes coding for resistance. This is assumed henceforth.

Plasmid DNA prepared on ethidium bromide/CsCl-gradients was analysed on sucrose gradients. The plasmid DNA from strain FAR 5 sedimented as two bands (Fig. 2a). Assuming that the open circular form of RPI-DNA sediments at $43 \mathrm{~S}$ (Grinsted et al. 1972) and that sedimentation is linear, the two bands of plasmid DNA from strain FAR 5 sedimented at about $43 \cdot 6$ and $3 \mathrm{I} \cdot 2 \mathrm{~S}$. Plasmid DNA from strain FAR $5 \mathrm{fus}^{-}, \mathrm{cad}^{+}, \mathrm{pen}^{+}$also showed two bands (Fig. $2 b$ ), which sedimented at about $4 \mathrm{I} \cdot 8$ and $30 \cdot 5 \mathrm{~S}$. The preparations of plasmid DNA used for the experiments illustrated in Fig. 2 were about 2 weeks old and had been frozen and thawed a number of times. When fresh, these preparations sedimented as a single band, at about $44 \mathrm{~S}$ for plasmid DNA from strain FAR 5 and $42 \mathrm{~S}$, for strain FAR 5 $\mathrm{fus}^{-}, \mathrm{Cad}^{+}, \mathrm{pen}^{+}$(data not shown). The appearance of a slower-sedimenting band of DNA in the preparations on ageing, and the ratio of $\mathrm{S}$ values of faster- to slower-sedimenting bands (about $\mathrm{I} \cdot 4: \mathrm{I}$ in each) is consistent with an assignment of a CCC configuration to the faster and an open circular form to the slower. Open circular DNA sedimenting at $3 \mathrm{I} \cdot 2 \mathrm{~S}$ and $30.5 \mathrm{~S}$ have molecular weights of about 16 million and 15 million daltons, respectively (Studier, 1965, Vinograd et al. 1965). (We realize that this small difference in molecular weights is not significant when based on the single experiments shown in Fig. 2. However, 


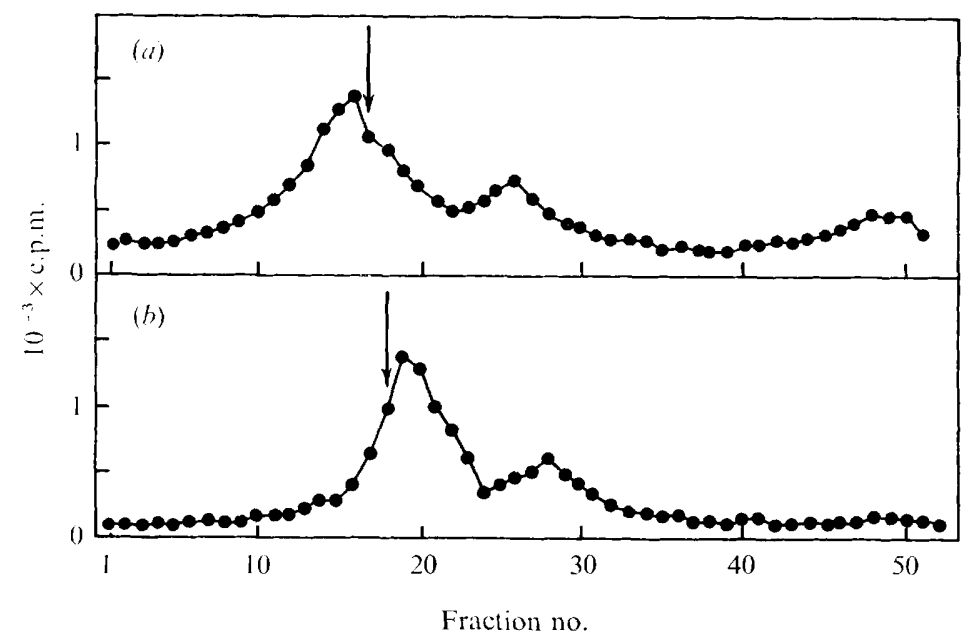

Fig. 2. Sucrose gradient centrifugation of plasmid DNA. Plasmid DNA was analysed on neutral sucrose density gradients. The open circular form of RPI-DNA (Grinsted et al. 1972) was used as a sedimentation marker and was centrifuged on parallel gradients: its peak position for each run is shown by the bold arrows. (After parallel runs, the gradient containing plasmid DNA and that containing the marker were fractionated into the same number of fractions.) (a) Plasmid DNA from strain FAR 5 (centrifugation was for I 20 min and 5I fractions were collected); (b) plasmid DNA from strain FAR $5 \mathrm{fus}^{-}, \mathrm{cad}^{+}, \mathrm{pen}^{+}$(centrifugation was for I $20 \mathrm{~min}$ and 52 fractions were collected).

these experiments have been repeated five times, and on every occasion this small difference has been observed.)

Thus, strain FAR $5 \mathrm{fus}^{-}, \mathrm{cad}^{-}, \mathrm{pen}^{-}$contains no detectable plasmid; strain FAR $5 \mathrm{fus}^{+}, \mathrm{cad}^{+}$, pen $^{+}$(FAR 5 wild) contains a single detectable plasmid of molecular weight of about 16 million daltons; and strain FAR $5 \mathrm{fus}^{-}, \mathrm{cad}^{+}, \mathrm{pen}^{+}$, which has lost resistance to fusidic acid, contains a single plasmid of molecular weight about 15 million.

\section{DISCUSSION}

On the basis of segregation studies, genes determining fusidic acid resistance were found to be linked with those determining cadmium-ion resistance and penicillinase production in four out of five strains of Staphylococcus aureus examined. However, in two of these four strains resistance to fusidic acid was sometimes lost independently of the other resistances. In one of these (strain FAR 5), all three resistances were usually transduced en bloc, indicating a single linkage group. This is located extrachromosomally as shown by the appearance of sensitive segregants spontaneously and absence of u.v. enhancement of the transduction frequency. A single extrachromosomal linkage group is further indicated by analysis of the DNA from strain FAR 5: only one extrachromosomal element was detected. This had a molecular weight of about 16 million daltons which is of the same order as that reported for another penicillinase plasmid (Rush, Gordon, Novick \& Warner (1969) report a plasmid of I 8.6 million daltons.) A derivative of FAR 5 which had lost resistance to fusidic acid while retaining resistance to cadmium ions and the capacity to synthesize penicillinase also contained only one detectable plasmid, of molecular weight about 15 million daltons. Thus, loss of fusidic acid resistance was accompanied by loss of a fragment of molecular weight about one million daltons from the plasmid. Presumably this fragment carried the gene(s) coding for this resistance. 
The aetiology of these associated elements is uncertain. There are three possible origins: (i) mutation to fusidic acid resistance on an existing penicillinase plasmid; (ii) an interaction between two different plasmids; (iii) recombination between chromosomal genes and a penicillinase plasmid. The mutational origin is unlikely as it was not demonstrable in vitro and on the grounds of probability, since the great majority of cellular DNA capable of undergoing mutation is chromosomal. Furthermore, the fragmentation of the linkage group in strains FAR 2 and 5 is difficult to explain on a mutational basis. It would therefore seem more likely that a recombination event has occurred whereby a fragment of DNA harbouring gene(s) for fusidic acid resistance is linked, sometimes unstably, to the penicillinase plasmid. Evidence supporting recombination is the apparent deletion of arsenate ion resistance from the penicillinase plasmid. Among other strains of Staphylococcus aureus, those that are resistant to cadmium ions have always been found to be resistant to arsenate (Richmond, 1969; Dyke et al. 1970).

Chromosomal genes may, on storage of the culture, become integrated into an existing staphylococcal plasmid (Asheshov, I966) and there is evidence for recombination between two plasmids under experimental conditions (Richmond, 1967). There is therefore a precedent for recombination of a plasmid with either chromosome or plasmid genes. Genes determining phage susceptibility have not been identified in staphylococcal plasmids; the association of such genes in strains FAR I and FAR 2 with the penicillinase plasmid may therefore favour a chromosomal origin for the fusidic acid resistance genes. If such a recombination event has occurred, it is uncertain to what extent it may have occurred de novo in various strains, or the degree to which interstrain spread of the associated plasmid has occurred.

This work was partly supported by grants from the Medical Research Council to Professor M. H. Richmond.

\section{REFERENCES}

AnNear, D. I. \& GrubB, W. B. (1972). Linked and unstable resistance to kanamycin and penicillin, and diffusible pigment production in an isolate of Staphylococcus aureus. Journal of Medical Microbiology $\mathbf{5}$, IO9-III.

Arber, W. (1960). Transduction of chromosomal genes and episomes in Escherichia coli. Virology II, $273-288$.

Asheshov, E. H. (I966). Chromosomal location of the genetic elements controlling penicillinase production in a strain of Staphylococcus aureus. Nature, London 210, 804-806.

Dyke, K. G. H., Jevons, M. P. \& Parker, M. T. (1966). Penicillinase production and intrinsic resistance to penicillins in Staphylococcus aureus. Lancet $\mathbf{i}, 835-837$.

Dyke, K. G. H., Parker, M. T. \& Richmond, M. H. (1970). Penicillinase production and metal-ion resistance in Staphylococcus aureus isolated from hospital patients. Journal of Medical Microbiology 3, I25-I 36 .

Evans, R. J. \& WATERWORTh, P. M. (I966). Naturally-occurring fusidic acid resistance in staphylococci and its linkage to other resistances. Journal of Clinical Pathology 19, 555-560.

Grinsted, J. Saunders, J. R., Ingram, L. C., Sykes, R. B. \& Richmond, M. H. (1972). Properties of an Rfactor which originated in Pseudomonas aeruginosa 1822. Journal of Bacteriology 1ro, 529-537.

LACEY, R. W. (197I). Transfer of tetracycline-resistance between strains of Staphylococcus aureus in mixed cultures. Journal of General Microbiology 69, 229-237.

Mitsuhashi, S., Hashimoto, H., Kono, M. \& Morimura, M. (1965). Drug resistance of staphylococci. II. Joint elimination and joint transduction of the determinants of penicillinase production and resistance to macrolide antibiotics. Journal of Bacteriology 89, 988-996.

Novick, R. P. \& BouAnchaud, D. (I97I). Extrachromosomal nature of drug resistance in Staphylococcus aureus. Annals of the New York Academy of Sciences 182, 279-294.

Richmond, M. H. (1967). Associated diploids involving penicillinase plasmids in Staphylococcus aureus. Journal of General Microbiology 46, 85-93. 
Richmond, M. H. (1969). Extrachromosomal elements and the spread of antibiotic resistance in bacteria. Biochemical Journal $\mathbf{1 r} 3,225-234$.

Rush, M. G., Gordon, C. N., Novick, R. P. \& Warner, R. C. (1969). Penicillinase plasmid DNA from Staphylococcus aureus. Proceedings of the National Academy of Sciences of the United States of America, 63, 1304-I310.

Studier, F. W. (1965). Sedimentation studies of size and shape of DNA. Journal of Molecular Biology II, 373-390.

Vinograd, S., Lebowitz, S., Radloff, R., Watson, R. \& Laipis, P. (1965). The twisted circular form of polyoma viral DNA. Proceedings of the National Academy of Sciences of the United States of America, 53, I I O4-I I II. 